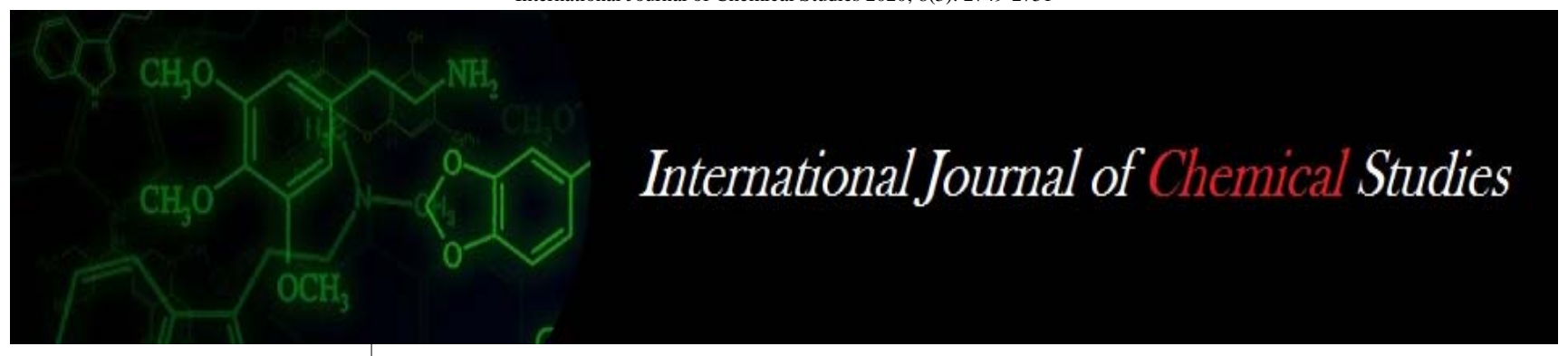

P-ISSN: 2349-8528 E-ISSN: 2321-4902 www.chemijournal.com IJCS 2020; 8(3): 2749-2751 (C) 2020 IJCS

Received: 23-03-2020 Accepted: 26-04-2020

Chetana Vasava

Department of Vegetable Science ASPEE College of Horticulture and Forestry Navsari Agricultural University Navsari, Gujarat, India

Archna Mahida Department of Fruit Science ASPEE College of Horticulture and Forestry Navsari Agricultural University Navsari, Gujarat, India

\section{Patel NK}

Department of Vegetable Science ASPEE College of Horticulture and Forestry Navsari

Agricultural University

Navsari, Gujarat, India

Dhara Gadhiya

Department of Vegetable Science ASPEE College of Horticulture and Forestry Navsari

Agricultural University Navsari, Gujarat, India

\section{Tandel BM}

Department of Fruit Science ASPEE College of Horticulture and Forestry Navsari Agricultural University Navsari, Gujarat, India

Corresponding Author: Chetana Vasava Department of Vegetable Science ASPEE College of Horticulture and Forestry Navsari Agricultural University Navsari, Gujarat, India

\section{Effect of spacing and foliar spray of micronutrients on quality attributes and economics of cluster bean (Cyamopsis tetragonoloba (L.) Taub.)}

\author{
Chetana Vasava, Archna Mahida, Patel NK, Dhara Gadhiya and Tandel \\ BM
}

DOI: $\underline{\text { htps://doi.org/10.22271/chemi.2020.v8.i3an.9627 }}$

\begin{abstract}
The present investigation entitled "Effect of spacing and foliar spray of micronutrients on quality attributes and economics of cluster bean [Cyamopsis tetragonoloba (L.)Taub]" was carried out at Vegetable Research Scheme, Regional Horticultural Research Station, ASPEE College of Horticulture and Forestry, Navsari Agricultural University, Navsari, Gujarat during summer 2017-18. The experiment was arranged with 12 treatments combination i.e. three levels of spacing (S), four levels of foliar spray of Micronutrient (F) and laid out in Randomized Block Design (Factorial concept) with three replications. The analysis of quality data revealed significance of individual effect foliar spray of $\mathrm{F}_{3}-\left(0.5 \% \mathrm{FeSO}_{4}+\right.$ $0.5 \% \mathrm{ZnSO}_{4}$ ) showed maximum crude fiber and crude protein. On economic point of view study revealed higher net return in $\mathrm{S}_{3} \mathrm{~F}_{3}$ treatment combination $\left\{(45 \mathrm{~cm} \times 30 \mathrm{~cm})+\left(0.5 \% \mathrm{FeSO}_{4}+0.5 \%\right.\right.$ $\left.\mathrm{ZnSO}_{4}\right)$ \} with higher BCR (1.97) followed by $\mathrm{S}_{1} \mathrm{~F}_{3}$ (BCR value of 1.16).
\end{abstract}

Keywords: Foliar spray, Crude Fiber, Crude Protein, Yield Attributes, Economics and BCR.

\section{Introduction}

Vegetable crops play crucial role in the economy of the country and play a pivotal role in the food and nutritional security of growing population. Cluster bean [Cyamopsis tetragonoloba (L.)Taub] popularly known as 'Guar' in India. It is one of the hardiest among all legume vegetables. The genus Cyamopsis includes three species but Cyamopsis tetragonoloba is only economically important species. The fleshy, long attractive green smooth tender pods with tender seeds, rich in vitamin A and iron are consumed as vegetable. Pusa Navbahar was high yielding, photo-insensitive and vegetable purpose variety. It is especially popular for longer and better quality pods. Legume crops require not only adequate macronutrients but also micronutrients for growth. Micronutrients are essential for the normal plant growth, deficiencies of which adversely affect the growth, metabolism and reproductive phase in plants. In recent years, Zinc is considered as one of the constraints in the optimum production of crops. It plays a vital role in the synthesis of chlorophyll, protein as well as nucleic acid. Zinc is the constituent of tryptophan which is a precursor of Auxin hormone (Hafeez et al., 2013). Iron play dominant roles in oxidoredox reactions of photosynthesis and respiration. The iron is a structural component of porphyrin molecules, cytochromes, hemes, haematin, ferrochrome as well as leghaemoglobin in involved which oxidation reduction in respiration or in root nodules and also an important part of the enzyme, Nitrogenase which is essential for nitrogen fixation through nitrating bacteria(Solanki et al., 2017) ${ }^{[6]}$.

\section{Material and Methods}

The field experiment was conducted at Vegetable Research Scheme, Regional Horticultural Research Station, Navsari Agricultural University, Navsari, Gujarat, India during Summer season of 2017-18 on cv. Pusa Navbahar to investigate the effect of spacing and foliar spray of micronutrients on quality attributes and economics of cluster bean. The experiment was conducted in Randomized Block Design with Factorial concept (FRBD) which included two factor namely, Factor one is Spacing (S) viz., $\mathrm{S}_{1}-45 \mathrm{~cm} \times 20 \mathrm{~cm} ; \mathrm{S}_{2}-45 \mathrm{~cm} \times 25 \mathrm{~cm}$; $\mathrm{S}_{3}-$

$$
\sim 2749 \sim
$$


$45 \mathrm{~cm} \times 30 \mathrm{~cm}$ and second factor is Foliar spray of micronutrients (F) $\mathrm{F}_{0}-$ Control (No spray); $\mathrm{F}_{1}-\mathrm{FeSO}_{4}-0.5 \%$; $\mathrm{F}_{2}-\mathrm{ZnSO}_{4}-0.5 \% ; \mathrm{F}_{3}-\mathrm{FeSO}_{4} 0.5 \%+\mathrm{ZnSO}_{4} 0.5 \%$ and 12 treatment combination viz., $1 . \mathrm{S}_{1} \mathrm{~F}_{0}-(45 \mathrm{~cm} \times 20 \mathrm{~cm}+$ control $)$; 2. $\mathrm{S}_{1} \mathrm{~F}_{1}-\left(45 \mathrm{~cm} \times 20 \mathrm{~cm}+\mathrm{FeSO}_{4} 0.5 \%\right) ; 3 . \mathrm{S}_{1} \mathrm{~F}_{2}-(45 \mathrm{~cm} \times 20$ $\left.\mathrm{cm}+\mathrm{ZnSO}_{4} 0.5 \%\right) ; 4 . \mathrm{S}_{1} \mathrm{~F}_{3}-\left[45 \mathrm{~cm} \times 20 \mathrm{~cm}+\left(\mathrm{FeSO}_{4} 0.5 \%\right.\right.$ $\left.\left.+\mathrm{ZnSO}_{4} 0.5 \%\right)\right] ; 5 . \mathrm{S}_{2} \mathrm{~F}_{0}-\left[45 \mathrm{~cm} \times 25 \mathrm{~cm}+\right.$ control]; $6 . \mathrm{S}_{2} \mathrm{~F}_{1}-$ $\left[45 \mathrm{~cm} \times 25 \mathrm{~cm}+\mathrm{FeSO}_{4}-0.5 \%\right] ; 7 . \mathrm{S}_{2} \mathrm{~F}_{2}-[45 \mathrm{~cm} \times 25 \mathrm{~cm}+$ $\left.\mathrm{ZnSO}_{4}-0.5 \%\right] ; 8 . \mathrm{S}_{2} \mathrm{~F}_{3}-\left[45 \mathrm{~cm} \times 25 \mathrm{~cm}+\left(\mathrm{FeSO}_{4} 0.5 \%+\right.\right.$ $\left.\mathrm{ZnSO}_{4} 0.5 \%\right)$ )]; 9. $\mathrm{S}_{3} \mathrm{~F}_{0}-\left[45 \mathrm{~cm} \times 30 \mathrm{~cm}+\right.$ control]; $10 . \mathrm{S}_{3} \mathrm{~F}_{1}-$ [45 cm $\left.\times 30 \mathrm{~cm}+\mathrm{FeSO}_{4}-0.5 \%\right] ; 11 . \mathrm{S}_{3} \mathrm{~F}_{2}-[45 \mathrm{~cm} \times 30 \mathrm{~cm}+$ $\left.\mathrm{ZnSO}_{4}-0.5 \%\right] ; 12 . \mathrm{S}_{3} \mathrm{~F}_{3}-\left[45 \mathrm{~cm} \times 30 \mathrm{~cm}+\left(\mathrm{FeSO}_{4} 0.5 \%+\right.\right.$ $\left.\left.\mathrm{ZnSO}_{4} \quad 0.5 \%\right)\right]$. The experiment included three replications. Time of first foliar spray of micro nutrients was at 30 DAS and second foliar spray at 45 DAS in early hours of morning. To record different field observations, five plants of cluster bean from each net plot area were selected randomly in the beginning and tagged with the labels.

The crude fibre content from cluster bean green pods was determined using method as described by Sadasivam and Manickam (1996) ${ }^{[4]}$. The crude protein content was estimated using Micro-kjeldahl method as described by Sadasivam and Manickam (1996) ${ }^{[4]}$. Looking for economics, gross return in terms of rupees per hectare was calculated based on green pod yield and prices in the market for each of the treatments. The cost of cultivation for each treatment was worked out by considering the cost of all operations right from the preparation of land to the harvesting of crop. Net return was worked out by subtracting total cost of cultivation from gross realization for each treatment and recorded in rupees per hectare.

\section{Results and Discussion}

The statistical comparison show the significant influence on different levels of foliar spray of micronutrients on crude fibre and crude protein. The $\mathrm{F}_{3}\left(0.5 \% \mathrm{FeSO}_{4}+0.5 \% \mathrm{ZnSO}_{4}\right)$ level of foliar spray of micronutrients recorded maximum crude fibre of 15.94 percent which was at par with $\mathrm{F}_{2}(0.5 \%$ $\mathrm{ZnSO}_{4}$ ). Significantly maximum crude protein of 26.92 was also percent under $\mathrm{F}_{3}$ which at par with $\mathrm{F}_{2}\left(0.5 \% \mathrm{ZnSO}_{4}\right)$ and $\mathrm{F}_{1}\left(0.5 \% \mathrm{FeSO}_{4}\right)$. The increased pod quality parameters in terms of crude fibre and protein because of combined zinc sulphate and iron sulphate foliar spray might be due to hydrolysis of complex polysaccharides into simple sugars synthesis of metabolites and rapid translocation of photosynthetic product and minerals from other parts of plant to developing pods. Such results were also supported by the findings of Bakry et al. (2011) ${ }^{[11]}$ in Fababean, Priyadarshini et al. (2017), Solanki et al. (2017) ${ }^{[6]}$ in cluster bean and Sale et al. (2018) ${ }^{[5]}$ in soybean.

The results revealed that among the different combination of treatments, $\mathrm{S}_{3} \mathrm{~F}_{3}\left\{45 \mathrm{~cm} \times 30 \mathrm{~cm}+\left(0.5 \% \mathrm{FeSO}_{4}+0.5 \%\right.\right.$ $\left.\mathrm{ZnSO}_{4}\right)$ \} observed the highest net profit 1,47,432 Rs. ha ${ }^{-1}$ with BCR value of 1.50 as compared to rest of the interaction effects, followed by $\mathrm{S}_{1} \mathrm{~F}_{3}$ (BCR of 1.16). Whereas, treatment $\mathrm{S}_{1} \mathrm{~F}_{0}\{45 \mathrm{~cm} \times 20 \mathrm{~cm}+$ (control) $\}$ recorded the lowest net realization of 29,023 Rs.ha $^{-1}$.

Table 1: Effect of spacing and foliar spray of micronutrients on crude fibre and crude protein from pod of cluster bean.

\begin{tabular}{|c|c|c|c|c|c|c|c|c|c|c|}
\hline \multirow{2}{*}{ Treatments } & \multicolumn{5}{|c|}{ Crude fibre (\%) } & \multicolumn{5}{|c|}{ Crude protein (\%) } \\
\hline & $\mathbf{F}_{\mathbf{0}}$ & $\mathbf{F}_{1}$ & $\mathbf{F}_{2}$ & $\mathbf{F}_{3}$ & S Mean & $\mathbf{F}_{\mathbf{0}}$ & $F_{1}$ & $\mathbf{F}_{2}$ & $\mathbf{F}_{3}$ & S Mean \\
\hline $\mathrm{S}_{1}$ & 14.58 & 15.41 & 15.67 & 16.07 & 15.43 & 19.00 & 26.61 & 26.35 & 26.47 & 24.61 \\
\hline $\mathbf{S}_{2}$ & 15.21 & 15.08 & 15.63 & 16.11 & 15.51 & 19.57 & 26.69 & 26.83 & 27.42 & 25.13 \\
\hline $\mathrm{S}_{3}$ & 15.02 & 15.53 & 15.50 & 15.63 & 15.42 & 19.74 & 26.51 & 27.11 & 26.87 & 25.05 \\
\hline \multirow[t]{2}{*}{ F Mean } & 14.94 & 15.33 & 15.60 & 15.94 & & 19.43 & 26.60 & 26.76 & 26.92 & \\
\hline & \multicolumn{2}{|l|}{$\mathrm{S}$} & \multicolumn{2}{|l|}{$\mathbf{F}$} & $\mathbf{S} \times \mathbf{F}$ & \multicolumn{2}{|l|}{$\mathbf{S}$} & \multicolumn{2}{|l|}{$\mathbf{F}$} & $\mathbf{S} \times \mathbf{F}$ \\
\hline S. Em. \pm & \multicolumn{2}{|c|}{0.12} & \multicolumn{2}{|l|}{0.14} & 0.25 & \multirow{2}{*}{\multicolumn{2}{|c|}{0.44}} & \multicolumn{2}{|l|}{0.50} & \multirow{2}{*}{$\begin{array}{c}0.88 \\
N S\end{array}$} \\
\hline C.D.at 5\% & \multicolumn{2}{|l|}{ NS } & \multicolumn{2}{|l|}{0.42} & NS & & & \multirow{2}{*}{\multicolumn{2}{|c|}{$\begin{array}{c}1.49 \\
6.13\end{array}$}} & \\
\hline C.V.\% & & & 2.7 & & & \multicolumn{2}{|l|}{ NS } & & & \\
\hline
\end{tabular}

Table 2: Effect of spacing and foliar spray of micronutrients on economics of Cluster bean.

\begin{tabular}{|c|c|c|c|c|c|c|c|c|c|}
\hline \multirow[b]{2}{*}{ Treatments } & \multirow{2}{*}{$\begin{array}{c}\text { Marketable } \\
\text { pod yield } \\
\text { (t ha-1) }\end{array}$} & \multirow{2}{*}{$\begin{array}{c}\text { Gross } \\
\text { return } \\
\text { (Rs.) }\end{array}$} & \multicolumn{5}{|c|}{ Cost of production (Rs.) } & \multirow{2}{*}{$\begin{array}{l}\text { Net Return } \\
\quad \text { (Rs.) }\end{array}$} & \multirow{2}{*}{$\begin{array}{c}\text { Benefit cost } \\
\text { Ratio }\end{array}$} \\
\hline & & & $\begin{array}{c}\text { Fixed } \\
\text { cost }\end{array}$ & \begin{tabular}{|c|} 
Treatment \\
cost
\end{tabular} & Cost-A & Cost-B & Cost-C & & \\
\hline $\mathrm{S}_{1} \mathbf{F}_{0}$ & 7.09 & 106350 & 50176 & 16992 & 70680 & 6647 & 77327 & 29023 & 0.38 \\
\hline $\mathrm{S}_{1} \mathrm{~F}_{1}$ & 9.10 & 136500 & 50176 & 20157 & 73845 & 8531 & 82377 & 54123 & 0.66 \\
\hline $\mathrm{S}_{1} \mathrm{~F}_{2}$ & 12.60 & 189000 & 50176 & 25632 & 79320 & 11813 & 91133 & 97867 & 1.07 \\
\hline $\mathbf{S}_{1} \mathbf{F}_{3}$ & 13.45 & 201750 & 50176 & 27057 & 80745 & 12609 & 93355 & 108395 & 1.16 \\
\hline $\mathrm{S}_{2} \mathbf{F}_{0}$ & 7.61 & 114150 & 50176 & 16529 & 70217 & 7134 & 77352 & 36798 & 0.48 \\
\hline $\mathrm{S}_{2} \mathrm{~F}_{1}$ & 10.15 & 152250 & 50176 & 20489 & 74177 & 9516 & 83693 & 68557 & 0.82 \\
\hline $\mathbf{S}_{2} \mathbf{F}_{2}$ & 8.66 & 129900 & 50176 & 18479 & 72167 & 8119 & 80286 & 49614 & 0.62 \\
\hline $\mathrm{S}_{2} \mathbf{F}_{3}$ & 9.70 & 145500 & 50176 & 20189 & 73877 & 9094 & $\begin{array}{l}82971 \\
\end{array}$ & 62529 & 0.75 \\
\hline $\mathrm{S}_{3} \mathrm{~F}_{\mathbf{0}}$ & 8.29 & 124350 & 50176 & 16689 & 70377 & 7772 & 78149 & 46201 & 0.59 \\
\hline $\mathrm{S}_{3} \mathrm{~F}_{1}$ & 10.89 & 163350 & 50176 & 20739 & 74427 & 10209 & 84637 & 78713 & 0.93 \\
\hline $\mathrm{S}_{3} \mathrm{~F}_{2}$ & 11.71 & 17650 & 50176 & 22194 & 75882 & 10978 & 86860 & 88790 & 1.02 \\
\hline $\mathbf{S}_{3} \mathbf{F}_{3}$ & 16.39 & 245850 & 50176 & 29364 & 83052 & 15366 & 98418 & 147432 & 1.50 \\
\hline
\end{tabular}

[Note: Cost B = Rental value of owned land @ 6.25\% income from gross return]

\section{Conclusions}

From this experiment we can concluded that, In light of the results obtained in the present investigation, it inferred that quality attributes potential of cluster bean can be increased by individual effect of foliar spray of micronutrients $\mathrm{F}_{3}(0.5 \%$ $\mathrm{FeSO}_{4}+0.5 \% \mathrm{ZnSO}_{4}$ ). From the economic point of view,
$\mathrm{S}_{3} \mathrm{~F}_{3}\left\{(45 \mathrm{~cm} \times 30 \mathrm{~cm})+\left(0.5 \% \mathrm{FeSO}_{4}+0.5 \% \mathrm{ZnSO}_{4}\right)\right\}$ was found more profitable in aspect of net realization.

\section{References}

1. Bakry BA, Elewa TA, Elkaramany MF, Zeidan MS, Tawfik MM. Effect of row spacing on yield and its 
components of some faba bean varieties under newly reclaimed sandy soil condition. World J Agric. Sci. 2011; 7(1):68-72.

2. Hafeez B, Khanif YM, Saleem M. Role of Zinc in Plant Nutrition-A Review. American J Experimental Agri. 2013; 3(2):374-391.

3. Priyadarshini S, Rawat GS, Dwibedi SK. Effect of levels of primary plant nutrients and row spacing on growth and yield Attributes of Some Promising Varieties of cluster Bean (Cyamopsis tetragonoloba L.). International $\mathrm{J}$ of Current Microbiology and Applied S. 2017; 6(12):17-27.

4. Sadasivam S, Manickam A. Biochemical Methods ( $2{ }^{\text {nd }}$ edn.), New Age International Publishers, New Delhi, India, 1996; 1-256.

5. Sale RB, Nazirkar RB, Thakare RS, Kondvilkar NB. Effect of foliar spray of zinc, iron and seed priming with molybdenum on growth and yield attributes and quality of soybean in the rainfed condition of Vertisol. International J Chemical Studies. 2018; 6(1):828-831.

6. Solanki RB, Yadav LR, Gupta A, Verma HP. Effect of foliar application of iron on cluster bean [Cyamposis tetragonoloba (L.) Taub] varieties. Research Environment Life Sci. 2017; 10(4):295-298. 